\title{
Blue Ocean Strategy for Improving Quality and Competitiveness of Islamic Educational Environment
}

Agus Zaenul Fitri ${ }^{1}$

${ }^{1}$ State Islamic University (UIN) Sayyid Ali Rahmatullah Tulungagung, Indonesia

\begin{tabular}{|c|c|}
\hline ARTICLE INFO & ABSTRACT \\
\hline $\begin{array}{l}\text { Article history: } \\
\text { Received: June } 18.2021 \\
\text { Revised: June 20, } 2021 \\
\text { Accepted: August 5, } 2021\end{array}$ & $\begin{array}{l}\text { Competition often makes someone do everything to achieve goals. } \\
\text { That happens because they aren't successful in innovating their } \\
\text { products, but only imitating and following their competitors. Blue } \\
\text { Ocean Strategy (BOS) offers a new strategy in competition, which } \\
\text { makes competitors, not enemies but makes them more motivated to }\end{array}$ \\
\hline $\begin{array}{l}\text { Keywords: } \\
\text { Blue Ocean Strategy, } \\
\text { Quality, } \\
\text { Competitiveness }\end{array}$ & $\begin{array}{l}\text { research studied BOS in Islamic educational institutions, which } \\
\text { includes mapping strategies in creating a market space where there } \\
\text { are no competitors, strategies in making the competition irrelevant, } \\
\text { and its implications in Islamic educational institutions. This study } \\
\text { used qualitative methods through field research type. Data obtained } \\
\text { through in-depth interviews, participant observation, and study of } \\
\text { documents. The results of this study concluded that: 1) The strategy }\end{array}$ \\
\hline Clonflict of Interest: & $\begin{array}{l}\text { of mapping educational institutions in creating market opportunities } \\
\text { that have no competitors is by creating innovations that do not yet }\end{array}$ \\
\hline None & exist in other levels of the educational institution; 2) Institutional \\
\hline $\begin{array}{l}\text { Funding: } \\
\text { None }\end{array}$ & $\begin{array}{l}\text { always showing innovations that are applied to other institution } \\
\text { without a cover-up (always open); 3) The implications of BOS in the } \\
\text { educational institution can be seen in terms of the output produced } \\
\text { which can be realized through graduates who can be used both in } \\
\text { companies and in educational institutions in need. }\end{array}$ \\
\hline
\end{tabular}

Corresponding Author: Agus Zaenul Fitri, ${ }^{1}$ State Islamic University (UIN) Sayyid Ali Rahmatullah Tulungagung, Indonesia, Indonesia, E-mail: guszain@yahoo.co.id

(C)

\section{Introduction}

\subsection{Introduce the Problem}

Rapid developments in technology have significantly disrupted the traditional business model (Saghiri, Wilding, Mena, Norlakis, 2017). Progress in the field of science and technology in the era of globalization makes the world of education place it in a very important position to help make it easier for students to understand the material presented. From this, the existence of technology is increasingly needed in educational institutions. Moreover, vocational education institutions are one of the schools that have the largest portion concerning technology. When faced with the dominance of technology in the world of education to achieve the goals of the institution, it is necessary to present innovation as a new style to be able to compete in the global scope of educational institutions. The existence of strategies, both in the world of education and the business world in general, was born from the thoughts of superiors on how to make an institution they lead more developed, sell well in the market, and have breakthroughs that other institutions have not. In the results of the assimilation of strategies between the worlds of education and business, there is 
a Blue Ocean Strategy (Kim\&Mauborgne, 2004, Mauborgne\&Kim, 2005). Blue Ocean Strategy is a business strategy that creates new market opportunities where competition does not exist using value innovation that creates something new that has no competitors (Rantisi \& Leslie, 20014). Sophistication in the era of globalization is increasingly demanding that people always transform into people who are sensitive to the advancement of science and technology. This automatically requires humans from the original to not understand at all, to have to start learning little by little the science of technology. These efforts are carried out with the aim that in the future humans will not only become humans who are blind to technology or just become users but makers creative. Especially in the world of education, the presence of technology is a very important thing to help make it easier for students to understand the material presented. Given that the purpose of education is to develop an awareness of the responsibility of every citizen towards the continuation of his life, not only to the environment of society and the state but also to humanity (Tilaar, 2008). So that every education actor, including students who are consumers of education, should also be able to blend with the world of technology so that later it will provide convenience in terms of teaching and learning activities. Various emerging technologies open the door of opportunity for the world both in the world of education, companies, and jobs to create innovation for innovation to support change movements that run in tune with the progress of the times. This is evident from innovations that appear in the present that are inseparable from the participation of world thinkers which are realized through the contribution of fresh ideas. The fresh ideas found are for example a strategy that can be used as a foundation for users to change the world. The strategy which adopts the terms in the corporate world has now been drawn and used in the world of education (Kim, 2016). The existence of strategies both in the world of education or the business world, in general, is born from the thought of superiors to how to make an institutional environment he leads can be more developed, sellable in the market, and have breakthroughs that are not owned by other institutional environments. One of the latest strategies and can be applied in educational institutions, namely BOS. Blue ocean strategy is a business strategy that creates new market opportunities where competition becomes non-existent using innovation that creates something new that has no competitors (Kim, 2005; Balaji \&Mayur, 2015). This strategy has been around for several years and was originally used in the business/ industrial world. The strategy of blue oceans illustrates that a business does not have to be fixated on what already exists in the market, but trying to find a gap that is different from the others can be even stronger than what is on the market so that its appearance becomes something that the community was very much awaited. In the business world, competition in the market is called a red ocean (Rafique, 2015). The fundamental reason for using red ocean and blue ocean metaphors because of red oceans seems to encapsulate the realities that are increasingly being faced by many organizations, while blue oceans encapsulate the unlimited possibilities that organizations can create from the beginning of industrial history.

Then the term red ocean used in the business world can be adopted into the world of education which also explains that the red ocean in question is a condition in which what already exists in an institutional environment has been applied by other institutional environments in the same way and process. So that there is no significant difference between educational institutions with one another. The existence of a BOS also has the goal of allowing any organization whether large or small, new or established, to be able to face the challenges of creating a blue ocean by maximizing opportunities and minimizing risks. The BOS seeks to escape the grip of competition. The point is an attempt to shift from competition to the creation of new market spaces and make competition no longer relevant. It is irrelevant to mean that there are no competitors who can compete with the existence of new ideas directly so that when they want to compete with the business owner, they already have innovations going forward (Lindič, Bavdaž, \& Kovačič, 2012). However, in the world of education, a competition that is no longer relevant is understood as a competition that is solely aimed at building cohesiveness between each educational institution to work together to build a stronghold of success in the world of education. One of the efforts taken is to implement a breakthrough that can be applied flexibly in every educational institution both Islamic and vocational. The thing that is the focus of this BOS is not to defeat the competitors but rather to try to offer additional value to consumers, to prioritize value innovation rather than position against competitors. To be able to run the BOS work tools are needed, which consists of a strategy canvas, a four-step framework, and a scheme create-reduce-enhance-create, so that it can provide a structure for what is historically an unstructured problem in terms of strategy, demonstrates the organization's ability to systematically create blue oceans. Theoretically, this research strengthens the theory of W. Chan Kim \& Renee Mauborgne (2005) that the BOS is a strategy to find breakthroughs and/or innovations related to the creation of a market space that has no competitors. Practically, this research shows that the BOS in improving the quality of education in educational institutions has a fairly important portion, especially in an era that is always experiencing rapid development as it is today.

\subsection{Explore Importance of the Problem}

ASHREJ Vol. 3, No. 2, 2021: 17-27 
Considering the presence of BOS both in the world of business, industry, or the world of education, it is increasingly considered important because considering the demands of an increasingly complex era. The reasons why the BOS is considered important are because:

1. Increasing influence and use of public "speakers".

2. There is a shift in a location in terms of future demand and growth.

3. Increased speed and convenience in becoming a global actor.

The presence of a BOS in the world of education will add a plus for every educational institution that has succeeded in bringing up innovations in its institution (Nioras, 2012). This will provide many positive benefits both for the institution itself or for all citizens in the institution. That way the institution will become a quality institution supported by continuous innovations. Research related to the BOS in educational institutions has so far been limited to studies related to the concept and its implications for educational institutions to advance in general. Considering how BOS is, it needs a significantly more in-depth study related to improving the quality of competitiveness and quality in the digital era. For example, Imam Satibi (Satibi, 2014) regarding the development of Vocational High Schools from the perspective of the Balanced Score Card and Blue Ocean Strategy shows that the BOS that is applied to superior vocational schools can find new strategies that make schools not preoccupied with matters of competition between schools. On the other hand, a school can easily manifest itself as a school of excellence which is marked by the distinction or specificity of the school. The advantages built by vocational high school (VHS) focus on core values as the school's identity. (Lindic, 2012) about Higher growth through BOS: Implications for economic policy aim to reveal a gap between the macro-level of economic policymaking to achieve higher growth and the microlevel of business growth. The findings call for a change in the focus of economic policies on specific size companies, industries, and business activities to intra-industry cooperation, a collaboration between companies of different sizes, value innovation, and creation of uncontested markets. In educational institutions, it can be said that VHS is one of the educational institutions that have more opportunities to create innovation. Supported by advanced technology facilities and quality human resources, it will provide a golden opportunity for vocational high school to flap their wings in implementing BOS to create innovations (Crespi. 2010). Seeing innovations increasingly emerging in VHS does not make equivalent to Islamic Senior High School (MA). This turned out to be able to raise the spirit of change in MA. Its manifestation is not a few public and Islamic educational institutions that are trying to create innovation by making the quality of education becomes better. But along with the progress of this era the world of education has not been able to compensate in its entirety. It seems that the world of education has not fully become a competitive world of students in positive terms. Not a few of the nation's next-generation seemed reluctant to show their image as a generation that cared about education. Education is often mistaken for them. They seem to have no matter how important the role of education is in themselves. So that almost every action even their speech does not at all reflect the next generation of an educated nation. Reflecting the increasingly sad reality of the world of education, the government is currently synergizing with education practitioners to begin to improve the quality of national education. The issue of education quality is indeed an issue that is always warm and interesting to discuss and study. The issue of quality education is in line with the demands of development and change (Handayani, 2014: 42). So it is not impossible if the quality of education is believed to be one of the pillars of human resource development which is very important for national development. It can even be said that the future of the nation lies in the existence of quality education at present and quality education will only emerge if there is a quality educational institution. Therefore, efforts to improve the quality of education are a strategic point in creating educational quality (Mulyasa, 2012: 16). To improve the quality of education, the inclusion of blue ocean strategies in educational institutions both Islamic and vocational is a form of fresh air that is believed to provide a slight change to the quality of education. Besides, efforts to improve the quality of education can be implemented, including holding training (workshop), providing adequate facilities and infrastructure, providing package books for each student, creating breakthroughs, and so on. All these efforts if done meticulously and sincerely undoubtedly can improve the quality of national education and the creation of effective schools are not mere figments.

Related to the implementation of the BOS in improving the quality of an educational institution, VHS and Islamic Senior High School became the educational institutions chosen in conducting this research. VHS is one of the strategic vocational high school pathways for investing in human resources. Whereas senior high school is an Islamic-based educational institution that can contribute to the development of the times by prioritizing good attitude and religious knowledge that is influential.

\section{Literature Review}

\subsection{Applying Blue Ocean Strategy}


Creating blue oceans is not a static achievement but a dynamic process. Once a company creates competitive advantages, and its superior performance is shown, sooner or later imitators begin to appear in the market (Shi-Chi Chang, 2010). Blue Ocean Strategy is a strategy to find breakthroughs and or innovations to improve the quality of educational institutions. Please note that Blue Ocean Strategy tries to create a space and fill it with something different from the others but still prioritizes marketing value. This is because this BOS is not solely aimed at getting out of market competition, but it aims to make competition irrelevant by expanding existing industry boundaries (Kim, 2016). Conditions that are irrelevant here in the sense of being able to come up with new ideas that cannot be rejected by the public can even provide a plus from the educational institution itself (value innovation). So in this case an analytical framework is needed so that this BOS can be implemented optimally. The quality of education is a description and overall characteristics of educational services both internally and externally that show their ability, satisfy the expected or implied needs including educational inputs, processes, and outputs (Sagala, 2009). The quality of education is not only determined by the school as a teaching institution but also adjusted to what the views and expectations of the community tend to always develop along with the times (Efendi, 2014). The BOS that was applied to superior vocational schools was able to find a new strategy that made schools not preoccupied with the business of competition between schools. On the other hand, a school can easily manifest itself as a school of excellence which is marked by the distinction or specificity of the school. The advantages built by VHS focus on core values as the school's identity. The adoption of the Blue Ocean Strategy principle into the world of education is quite good, meaning that it is very possible to apply it to other Islamic institutions. For an issue that is still being debated among education experts (Fuad, 2016). Strategy as a business model in education does not deserve to be ignored or otherwise absolutely accepted. This means that the adoption of the blue ocean principle is not perfect, because after all, educational institutions are not like other companies that are purely for profit. If the adoption is close to or has reached a perfect point, it indicates that the school has been commercialized and ignores the values that are principled in education as a social institution.

\subsection{Blue Ocean Strategy in Educational Institution}

The application of BOS can be done for universities. The key to success is a broader view of consumers and the establishment of activities that provide utility to potential consumers. In implementing the BOS of higher education institutions, it is necessary to pay attention to the differences and similarities in the characteristics of universities compared to companies (Kim\&Kim, 2007). Especially in looking at what is meant by benefits for universities. It is also necessary to pay attention to student capacity, not all applicants can be accepted, but with increasing numbers (Utama, 2008). Applicants (interested potential consumers) are likely to get more qualified prospective students and think about not giving any qualified prospective students to other universities. Good prospective students will be easier to educate and become quality graduates who will satisfy consumers in a broader sense, namely all stakeholders. Stakeholder satisfaction is the ultimate goal of the success of higher education and will raise the name of the university. To win the competition, universities need to implement the BOS in the form of increasing student skills and soft skills and opening new Departments of Study Programs that are much needed by the market, including the Diploma III Medical Record study program. Portfolio applications are mapped into McFarlan Portfolio consists of SI Key Operations, SI Support, Strategic, and High Potential. (Sarkhawi, 2005). T-Gongsin created an online learning program that is offered as a form of action away from the existing competition (divergent). Currently, KT-Gongsin is in the stage of carrying out its motto, namely "Dream, Study, Global" through an online learning program. The success or failure of a strategy is very dependent on how big the level of suitability of the strategy is with the company's conditions. The use of mobile applications in the teaching and learning process is a new thing offered by KT-Gongsin. The use of this application requires good and correct socialization to all parties related to KT-Gongsin, especially to students and mentors. When this strategy has been implemented, it is necessary to add one new division in the composition of KT-Gongsin, namely the mobile and application division (Eka, 2008), add your voice to wherever you think is needed.

In general, this research will examine the BOS (Blue Ocean Strategy) in improving the quality of education, so the researchers start from the Blue Ocean Strategy which makes value innovation the basis of work. However, previously, the researcher emphasized that there are 5 main characteristics of BOS, of which 2 of them are the focus of this study. The 2 points are related to the creation of market opportunities where there are no competitors and how to create competition that is no longer relevant. Furthermore, by applying the three frameworks, which include the strategy canvas, the four-step framework, and the eliminate-reduceincrease-create scheme, a BOS can be realized. All of the three frameworks can be implemented through the cooperation of all educational personnel so that the goal of improving the quality of education can be achieved. The quality of education referred to by the researcher is limited only to the process and output. The process relates to learning, service, and innovation development while the output includes graduates and

ASHREJ Vol. 3, No. 2, 2021: 17-27 
customer satisfaction (both internal and external). So that the existence of the BOS can make a contribution that can improve the quality of education and have an impact on the progress of the educational institution itself.

\section{Method}

This study used field research by a qualitative descriptive approach and using a multi-case design. The presence of researchers in the field is a must because in this study researcher was a key instrument in collecting data. The location of the research in this study is located in VHSI 1 Blitar and MA Darul Huda Wonodadi Blitar. The research data source was divided into three, namely: people, places, and documents. The three data sources were used to complement each other's information and data. In collecting data, researchers used observation, in-depth interviews, and documentation. The researcher analyzed the data with a single case analysis based on opinions from Miles and Huberman (1992), which included data collection, data reduction, data verification, and conclusion drawing. After a single case analysis, a multi-case analysis was conducted (Sugiyono, 2013). To check the validity of the data, the researcher conducted an extension of the time of the study, triangulation, collected many references, reviewed the data to be proven, and clarified the data informants.

\section{Results and Discussion}

\subsection{Blue Ocean Strategy (BOS) in Education}

Related to the concept of BOS, the term strategy contains understanding which is a kind of company plan in determining their future. The plan in question covers three different levels, including a corporate strategy that relates to different businesses or product lines. Second, business strategy is related to positioning products (Manuel, 2011). As well as functional strategies related to typical competencies that can create a competitive advantage. BOS is a strategy formula that breaks down the assumptions of conventional strategies. This strategy focuses on creating market space without competitors while making the competition irrelevant (Kim, 2016). Value orientation is oriented to the entire system of companies to bring together the value expected by buyers to the company. The BOS is characterized by unexplored market space, demand creation, and opportunities for profitable growth (Septarini, 2014). BOS can be created from something completely new or a pre-existing condition. The first theory that emerged about the BOS was first coined by Cirque du Soleil which was later popularized by two management professors namely W. Chan Kim \& Renee Mauborgne. To understand what Cirque du Soleil has achieved, it is necessary to memorize the existing situation in a market consisting of two oceans, namely red oceans and blue oceans. The red ocean describes all industries that exist today. This is a well-known market space. Whereas the blue ocean represents industries that do not exist now. This is an unknown market space that the blue ocean wants to enter. In red oceans, boundaries in the industry have been determined and accepted, and competition rules are known. Here if it is drawn into the world of education, an educational institution seeks to defeat opponents to gain a greater market share of demand. In contrast, the blue ocean strategy is characterized by untapped market space, demand creation, and very profitable growth opportunities. Although some blue oceans were created really outside the existing industry, most blue oceans were created from within the red ocean by expanding existing industry boundaries. From what has been experienced by Cirque du Soleil, then W. Chan Kim \& Renee Mauborgne (2016) work together to enter the world of BOS to find something unique about that strategy. The peculiarity of the BOS in question was able to make a far leap that could even outperform the other companies by not winning the competition but using the space that was still not controlled by the market. By reinforcing various analytical frameworks that have been compiled, the BOS can be applied in the corporate world to penetrate the world of education.

\subsection{Work Platform BOS}

In the business world, many reasons encourage every company to create a new market space. Rapid technological advancements substantially increase industrial productivity and enable companies to produce products and services. When the number of competitors increases and supply exceeds demand, the monopoly of the market by certain companies that has been happening has faded. As a result, the commoditization of products and services is getting faster and the price war cannot be avoided so that the profits derived shrink. The only way to win the competition is to stop competing and switch to exploring the blue ocean. The competition is made irrelevant because new game rules will be formed (Fuad, 2016). This is different from the red ocean where defeating competitors will always be important. Indeed, the above exposure is also experienced by the world of education. If in the business world competition by defeating and shutting down competitors is considered natural, then in the world of education it is something that is difficult to accept and feels unethical. Educational institutional environments both Islamic, public, and vocational should strengthen each other by the vision and mission and try to develop knowledge, not even dragged into a competition that harms and kills each other (red oceans). The majority of educational institutions do not immediately turn to 
the largely uncharted blue ocean. Educational institutional environments indirectly carry out the division of jobs from educational assignments that are large and cover various kinds of aspects that cannot be handled by only one or two educational institutions. The creators of BOS do not use competition as a reference, but instead, use strategic logic that is different from other strategies better known as value innovation. This value innovation is the foundation of a BOS that focuses on making competition between educational institutions irrelevant by creating a leap in value for consumers. So that BOS provides an opportunity for an institutional environment to open a new market space without competitors. Value innovation provides an equal emphasis on value and innovation. Value without innovation tends to focus on large-scale value creation, something that increases value but is not sufficient to make educational institutions exist in the market. Whereas innovation without value tends to be technology-dependent, market pioneering, or futuristic, and often aiming for something that is not ready to be accepted and consumed by the public. Value innovation occurs only when an educational institution combines innovation with utility, price, and cost position. Many strategic choices for educational institutions to pursue differentiation and low costs by following the principles of the creation of the blue ocean that Kim and Mauborgne put. It is different from what competes based red ocean strategy which is in large cost differentiation because the institutional environments compete based on the same rules of successful practice. Whereas in the BOS strives to make success by breaking down the value-added tug.

\subsection{Job Analysis Tool of BOS}

There are six principles in BOS which are divided into two clusters, namely strategy formulation clusters and strategy execution clusters. The strategy formulation cluster consists of four principles, namely reconstructing market boundaries, focusing on the big picture rather than numbers, reaching beyond the existing demand, and doing a series of strategies appropriately. While the strategy execution cluster includes two principles, namely efforts to overcome organizational barriers and integrate execution into the strategy.

\subsubsection{Reconstructing Market Constraints}

In reconstructing the limits of the existing education market, managers of Islamic Vocational High School have many considerable alternative fields, looking at strategic groups and mapping consumers. In grouping according to the vocational and competency of students, it is certainly balanced with educators who are clustered into the appropriate fields. Strategic groups within it are easily detected and the consumer community can be mapped so that education can be delivered without being involved in competition with other institutional environments. This principle automatically minimizes search risk and the opportunity to navigate the blue ocean.

\subsubsection{Focus on the Big Picture}

Focus on the big picture, meaning that every manager must visualize his strategy in a canvas that summarizes the current situation of known market space and the position of the institutional environment he leads. With the strategy canvas, it can be understood what factors are becoming a venue for competition in products and services and what competitive offerings are on the market. Engineering in the strategy canvas will form a company/institutional environment making a fundamental new leap rather than mere statistical figures. With this step, the institutional environment is directed from focusing on competitors to alternatives, from consumers to non-consumers. From the strategy canvas that contains a large picture of existing industrial markets, managers then take steps more practical with a four-step framework (Tander, 203). This four-step framework aims to break down the tug between differentiation and low cost and create a new value curve. To create this, four main questions are needed as a key to challenging the strategic logic and business model, including: (1) what factors have been taken for granted by the industry that must be eliminated?, (2) what factors must be reduced to below industry standards?, (3) what factors should be increased to above the industry standard?, and (4) what factors must be created, which the industry has never offered? In addition to the two work analysis tools such as the strategy canvas and the four-step framework, there is also a third analytical tool that is important in creating a BOS. This tool is a complementary analysis tool for the fourstep framework called the scheme reduce-increase-create-elimination. This scheme encourages companies not only to ask four questions in a four-step framework but to create a new value curve. Because the completion of efforts in this scheme is a challenging task, this scheme encourages institutional environments to be enthusiastic in analyzing every industry factor that becomes a competition arena, so that they find various implicit assumptions made unconsciously in the competition.

\subsubsection{Reaching beyond demand}

To reach beyond existing demand, companies/institutional environments must oppose conventional practices about consumers, namely focusing on existing customers and sharpening segmentation on the part of buyers. Managers must take the opposite path of needing to look to non-consumers and develop things that have not 
been appreciated by buyers in general. The non-consumer world in general offers great opportunities to create blue oceans, only a few companies have insight into who is non-consumers and how to open their world.

\subsubsection{Conducting a strategic}

Series The set-up serves to ensure its continuity commercial and reduce the risk of the business model it applies. The starting point of this series is the utilities special that are owned, setting the right strategic prices, ensuring strategic profits, and facing obstacles adopting rolling out the idea of the BOS.

\subsubsection{Overcoming Organizational Barriers}

The BOS guides step managers to abandon the company's status quo based on the shift from convergence to divergence in the value curve with low costs. A manager is faced with four organizational barriers, namely to make aware employees of the importance of strategic displacement (barriers cognitive), limited resources, motivation, and obstacles political. To be able to overcome these obstacles effectively, a manager must be able to portray a role leadership called a leadership tipping point that is a leadership model that opposes general knowledge that views more and more changes made, the more resources and time needed (Mulyadi, 2010). From the above explanation, we can draw a red thread that BOS is a business strategy that creates new market opportunities where competition becomes non-existent (irrelevant) using innovation that creates something new that has no competitors (Kim, 2004). Then to implement the BOS, a combination of work tools is needed, such as a strategy canvas, a four-step framework, scheme to create reduction-reducingcreating that synergizes with one another so that the goal of improving the quality of education can be maximally achieved.

\subsection{The Nature of Educational Quality}

There are many opinions from experts related to the definition of quality, just as Juran (1999) states that quality is a match for the use of products (fitness for use) to meet customer needs and satisfaction. Crosby (1979) also explained that quality is conformance to a requirement that is by what is implied or standardized, that is following predetermined quality standards both input, process, and output. Then, Deming (1986) also explained that quality is following a market or consumer needs. Besides, Feigenbaum (1999) as quoted by Nasution (2001) also explained that quality is full of customer satisfaction. Often the quality is synonymous with quality. In creating good quality in all fields, even in the fields of education, technology, or even health, everything is inseparable from the minimum quality standard itself. In general, according to the Ministry of National Education, as quoted by Mulyasa (2012), he said that quality can be interpreted as a description and overall characteristics of goods or services that show their ability to satisfy the expected or implied needs. In the context of education, the definition of quality refers to inputs, processes, outcomes, and impacts. The quality of input can be seen from several sides. First, the condition of whether or not the input of human resources is good, such as principals, teachers, laboratory staff, administrative staff, and students. Second, whether or not the material input criteria are in the form of props, books, curriculum, infrastructure, school facilities, and others. Third, whether or not the input criteria are in the form of software, such as regulations, organizational structure, job descriptions, and organizational structure. Fourth, the quality of input in the form of expectations and needs, such as vision, motivation, perseverance, and ideals (Danim, 2008). Whereas in the context of Total Quality Management (TQM), quality is a different matter. Quality is not just an initiative but is a philosophy and methodology that helps institutional environments to plan change and set agendas in the face of excessive external pressures (Sallis, 2012).

Both in the context of education and the context of TQM, all efforts made together aim to satisfy school customers (internal and external). The good steps sought are the foundation of an educational institution to be able to build an image for the community. Emphasis on responsibility, effectiveness, and efficiency is very calculated considering that education consumers come from a variety of different backgrounds. Regarding the responsibility, effectiveness, and efficiency of this following the word of God in Surah Al-Zalzalah (99): 7-8, as follows: "So, whoever does an atom's weight of good shall see it, and whoever does an atom's weight of evil shall see it." It means that the value of responsibility is a matter that must be considered and prioritized, and becomes an emphasis on all activities carried out in everyday life. A good and well-executed intention and planning will produce something good. Vice versa, intentions, and implementation that are not goodwill produce something that is not good or leads to destruction in the organization (Mutohar, 2013). Seeing many opinions about quality, it can be concluded that quality is a matter related to customer satisfaction, strives to achieve expectations, and becomes vital in improving institutional environments.

Furthermore, discussing education, in the Republic of Indonesia Law No. 20 the Year 2003 Chapter I Article I paragraph (1) has been stated that education is a conscious and planned effort to create a learning atmosphere and learning process so that students actively develop their potential to have spiritual power religion, self-control, personality, intelligence, noble character, and skills needed by him, society, nation, and 
country. Then Good Carter V, as quoted by Rochaety, et al, also added that education is (1) a person's process of developing abilities, attitudes, and other behaviors in the communities in which they live; (2) The social process that occurs in people who are faced with the influence of the chosen and controlled environment (especially those coming from the school) so that they can obtain optimal development of social abilities and individual abilities (Rochaety, 2006. Education is influenced by the environment on individuals to produce changes that are permanent in behavior, thoughts, and attitudes. The role of education does have a significant influence on the progress of the nation and state. Through education, all levels of society can learn a lot of knowledge so that they automatically obtain good information that they need or information that only aims to inform even though they are not very concerned. Especially during the hustle and bustle of the progress of the all-digital era, including those relating to this information, the existence of education is increasingly enhanced. So that education can show its performance to the maximum and produce output quality.

\subsection{Management Characteristics of Educational Quality}

In the context of education, if someone says that the school is qualified, it can be interpreted that the graduates are good, the teacher is good, the building is good, and so forth. Quality itself is related to efforts to provide satisfactory services for users of educational services. In the organization of education systems, quality aspects will also always concerned with how the input of students, the process of education with a focus on the service of learners, to how output graduates generated (Sujanto, 2014).

Improving the quality of education is the target of development in the field of national education and is an integral part of efforts to improve the quality of Indonesian people. As stated in the national education system law article 3 number 20 of 2003 stated that:

"That national education functions to develop capabilities and shape dignified national character and civilization to educate the nation's life, aiming at developing potential students to become human who has faith and devotion to God Almighty, has a noble character, is healthy, knowledgeable, capable, creative, independent, and become citizens who are democratic and responsible".

Quality must be sought to achieve progress based on a planned change. In seeking to improve the quality of education, there are characteristics of the quality itself according to Usman as quoted by Efendi (2014), namely (1) performance: relating to the functional aspects of the school; (2) teaching time; (3) reliable: have long-lasting service; (4) strong endurance; (5) beautiful; (6) human relations: upholding moral values and professionalism; (7) easy to use; (8) certain standards; (9) consistency; (10) uniforms: without variation; (11) able to serve; (12) accuracy in service. Referring to these quality characteristics, to improve the quality of education, the 12 characteristics above are used as their size. Besides, even education observers and practitioners of education do not rule out how quality education indicators so that they do not experience fatal errors. There are several indicators of quality education, including: (1) the result of education is the ultimate goal of education; (2) the direct results of education can be in the form of knowledge, attitudes, and skills; and (3) the educational process in which students use buildings, facilities, and other facilities and infrastructure to achieve maximum teaching and learning activities. Through various good characteristics of the quality of education, it is not difficult for education practitioners to try to improve the quality of education. To produce output educational that is of high quality and able to compete in the world, it would be quite easy if both students and educators had the same vision and mission. If only one of the parties is keenon improving the quality of education (printing the best graduates), on the other hand, it does not respond quickly and responsibly, then everything is just nonsense. Because actually, the location of the success of education is in the awareness of all elements of education itself.

\subsection{Educational Quality Improvement Strategies}

Quality or quality is often interpreted in a variety of ways, depending on the point of view where the concept is interpreted. To the quality of education, this understanding must be related to what is produced and who uses education. This definition refers to the added value provided by education and the parties who process and enjoy educational outcomes. To improving the quality of education, the application of the concept of Total Quality Management (TQM) in the world of education is needed. TQM itself can be understood as a management system that focuses on people or customers that aims to increase satisfaction customers on an ongoing basis with minimum costs. Continuous efforts are what make TQM an approach in meeting the needs, desires, and expectations of its customers, both now and in the future. TQM concept in education views educational institutions as a service industry and not as a production process. TQM, in this case, does not discuss the problem of input (learners) and output (graduates), but about customers who have the needs and ways to satisfy these customers. So that it can be said that TQM views educational business products as services in the form of services provided by education managers and all employees to customers following 
certain quality standards. Understanding that the presence of TQM in educational institutions is something that is needed, the participation of all school members in the success of implementing TQM is also expected. This is because actually what is called quality education is not only seen from the quality of its graduates but also covers how educational institutions can cover all the needs of their customers (internal and external) following applicable quality standards. So that the creation of a quality educational institution becomes a real thing that can be felt by all education users. The result of this research was: (1) both institutions were good, they moved to create innovations aimed at improving the quality of education in these educational institutions. this also has an impact on efforts to empower graduates to be recruited by stakeholders following their expertise; (2) both institutions tried to open relationships to expand market reach. the effort to open relationships with several companies for vocational high school as a major opportunity to develop institutional environments so that they can get an adequate portion about the distribution of graduates and field practice activities; (3) the implications are seen in both educational institutions can be known in terms of output produced. The output included the acceptance of institutional environments as the center of graduate mediators, the number of new parents and prospective students who trust educational institutions, and also trusted by several other educational institutions to always open networks with several companies.

\section{Conclusion}

Based on the results of the discussion and study above, the conclusions can be drawn as below. First, strategies of educational institutions in creating market spaces that there are no competitors including the following: (a) creating varied innovations to make educational institutions able to survive in the present, (b) launching a breakthrough every year, (c) always open with other educational institutions even though the educational institution wants to adopt innovations that were born by Islamic vocational high school. Second, the educational institution's strategy in making competition not relevant at Islamic vocational high school covers the following: (a) Islamic vocational high schools do not view other educational institutions as competitors but assume that educational institutions it is necessary to build cooperation to create good synergies between educational institutions; (b) Islamic vocational high school make other educational institutions as partners to advance educational institutions and expertise especially in Islamic vocational high school and advance on job practical program as well as devotion to a student; (c) embrace all graduates from both their educational institutions and other educational institutions to jointly provide facilities to produce quality educational output. Third, The implications of BOS in Improving the quality of education in Islamic vocational high school include the following: (a) innovations created in educational institutions has succeeded in improving the quality of education, especially in terms of output; (b) innovations created in educational institutions were able to bring interest to the public to send their children to school in the two educational institutions; (c) innovations created can train students to be more active and provide good opportunities for the future so that they can be recruited by companies for graduates.

\section{Acknowledgments}

The researcher of this study wants to thank all those who had provided support and officially licensed so that I can complete this research. I also want to express thank all informants for giving us time to interview and providing the necessary data needed to analyze in this study.

\section{References}

Balaji, M., \& Mayur, K. (2015). Blue ocean strategy of Apple: From iPod to iPad. Available at https://www.slideshare. net/MayurSurani/apple-blue-oceanstrategy

Bedjo Sujanto, (2007). Guru Indonesia dan Perubahan Kurikulum: Mengorek Kegelisahan Guru, Jakarta: Sagung Seto,

Chang, S. C. (2010). Bandit cellphones: A blue ocean strategy. Technology in Society, 32(3), 219-223. https://doi.org/10.1016/j.techsoc.2010.07.005

C. Kim, K. H. Yang, J. Kim. A strategy for third-party logistics systems: A case analysis using the blue ocean strategy, Omega, Vol. 36:4, 2007, 522-534.

Crespi, G., Zũniga, P., 2010. Innovation and Productivity: Evidence from Six Latin American Countries. Inter-American Development Bank, Washington.

Crosby, Philip B. (1979). Quality is Free, Mc-Graw Hill Book, New York.

Deming, W. Edwards, (1986). Out of Crisis. Massachusetts Institute of Technology, Centre for Advanced Engineering Study, Cambridge.

E. Mulyasa, (2012). Manajemen \& Kepemimpinan Kepala Sekolah, Jakarta: Bumi Aksara, 
Edward Sallis, (2012). Total Quality Management in Education: Manajemen Mutu Pendidikan, terj. Ahmad Ali Riyadi \& Fahrurrozi, Jogjakarta: IRCiSoD,

Eka Chandra Septarini, (2014). Perumusan Strategi Samudra Biru KT-Gongsin", Tesis, Yogyakarta: Universitas Atma Jaya,. Lihat juga http://e-journal.uajy.ac.id/6158/1/Jurnal\%20MM01756.pdf.

Eti Rochaety, dkk, (2006). Sistem Informasi Manajemen Pendidikan, Jakarta: Bumi Aksara,

Feigenbaum, A.V, (1999). Total Quality Control. Third Edition, McGraw Hill, Inc., New York.

Fernandes, Manuel. T, (2011). Business Strategy Model. International Journal of Innovation, Management and Technology", Vol. 2, No. 4.

Hidayati, (2014) . Manajemen Pendidikan, Standar Pendidik, Tenaga Kependidikan, dan Mutu Pendidikan”, Jurnal Al-Ta'lim, Volume 21, No.1.

Ikhwan Fuad, (2016). Blue Ocean Strategy (BOS) sebagai Paradigma Baru Manajemen Pendidikan Islam, Jurnal Ilmu Tarbiyah al-Tajdid, Vol.5, No.2

Juran, J.M \& Blanton Godfrey, Fift Edition, (1999). Juran Quality Handbook. McGraw-Hill Company. New York.

Kim, W. C., \& Mauborgne, R. (2004). Blue ocean strategy. Harvard Business Review. Available at https://hbr.org/2004/10/blue-ocean-strategy

Lindič, J., Bavdaž, M., \& Kovačič, H. (2012). Higher growth through the Blue Ocean Strategy: Implications for economic policy. Research Policy, 41(5), 928-938.https://doi.org/10.1016/j.respol.2012.02.010

M. Rafique, R. D. Evans, M. T. Nawaz. Absorptive capacity: a hub of Blue Ocean and red ocean strategies and capability transformation in innovative business environments. International Conference on KnowledgeBased Engineering and Innovations, Tehran, Iran, 2015.

Matthew B. Miles and A. Michael Huberman, (1992). Analisis Data Kualitatif. Cet I. Terj. Universitas Indonesia.

Mauborgne, R. A., \& Kim, W. C. (2005). Blue ocean strategy: How to create uncontested market space and make the competition irrelevant. Brighton, MA: Harvard Business School Press

Mika Lohtander, Antti Aholainen, Jarno Volotinen, Merja Peltokoski, Juho Ratava. (2017). Location Independent Manufacturing-Case-based Blue Ocean Strategy. Procedia Manufacturing 11.

Mulyadi,( 2010). Kepemimpinan Kepala Sekolah: dalam Mengembangkan Budaya Mutu, Malang: UIN Maliki Press,

Nasution MN,( 2001). Manajemen Mutu Terpadu: Total Quality Management, Jakarta: Ghalia Indonesia,

Nioras A., (2012) Regional Innovation Monitor, Regional Innovation Report: Attica

Nur Efendi, (2014). Membangun Sekolah Efektif dan Unggul: Strategi Alternatif Memajukan Pendidikan, Jogjakarta: Lentera Kreasindo.

Nur Efendi, Membangun Sekolah Efektif dan Unggulan: Strategi Alternatif Memajukan Pendidikan, (Yogyakarta: Lentera Kreasindo, 2014), 321.

Prim Masrokan Mutohar, (2013). Manajemen Mutu Sekolah: Strategi Peningkatan Mutu dan Daya Saing Lembaga Pendidikan Islam, Jogjakarta: Ar-Ruzz Media,

Sudarwan Danim, (2008). Visi Baru Manajemen Sekolah: dari Unit Birokrasi ke Lembaga Akademik, Jakarta: Bumi Aksara, 2008.

Sugiyono,( 2013). Metode Penelitian Kuantitatif, Kualitatif, dan R\&D, Bandung: Alfabeta.

Syaiful Sagala, Manajemen Strategik dalam Peningkatan Mutu Pendidikan: Pembuka Ruang Kreativitas, Inovasi, dan Pemberdayaan Potensi Sekolah dalam Sistem Otonomi Sekolah, (Bandung: Alfabeta, 2009), 170.

Saghiri, S., Wilding, R., Mena, C., \& Bourlakis, M. (2017). Toward a three-dimensional framework for omni-channel. Journal of Business Research, 77, 53e67.

Tilaar, (2008). Manajemen Pendidikan Nasional: Kajian Pendidikan Masa Depan, Bandung: PT Remaja Rosdakarya.

W. Chan Kim \& Renee Mauborgne, (2004). Blue Ocean Strategy. Harvard Business Review.

ASHREJ Vol. 3, No. 2, 2021: 17-27 
W. Chan Kim, Renée Mauborgne, (2005), Value innovation: a leap into the blue ocean, Journal of Business Strategy, Vol. 26 Issue: 4

W. Chan Kim \& Renee Mauborgne, (2016). Blue Ocean Strategy: Menciptakan Ruang Pasar Tanpa Pesaing dan Menjadikan Persaingan tidak Lagi Relevan, Jakarta Selatan: Noura Books, 6.

W Chan Kim\&Renee Mauborgne (2016), Blue Ocean Strategy: Menciptakan Ruang Pasar Tanpa Pesaing dan Menjadikan Persaingan Tidak Lagi Relevan, terj. Adi Toha, (Jakarta: Noura Books). 